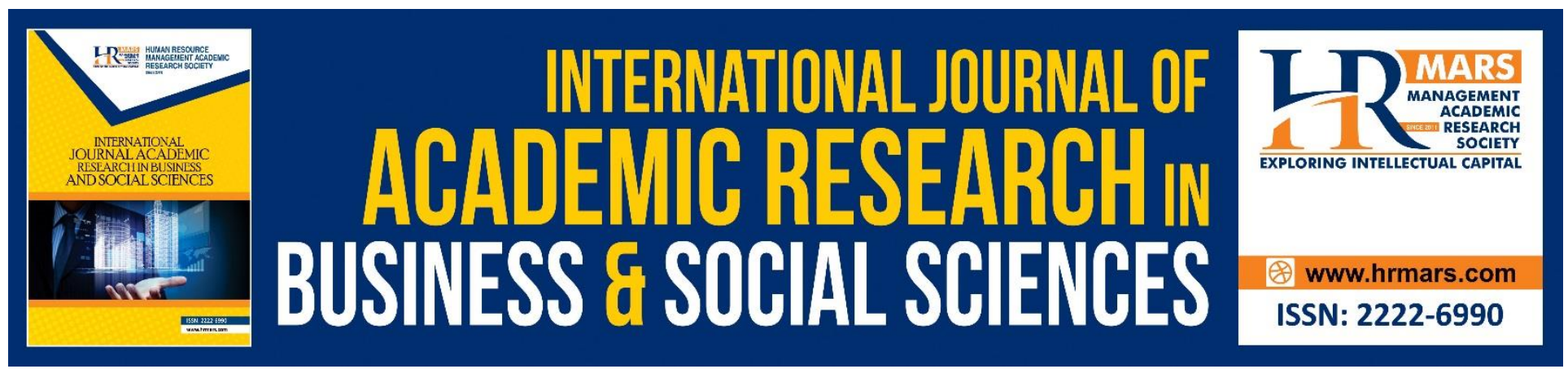

\title{
Determinants of Agents Performance: A Case Study of AmMetLife Malaysia Berhad
}

\author{
Amirul Afif Muhamat, Norzitah Abdul Karim, Siti Aminah Mainal, \\ Sharifah Faigah Syed Alwi \& Mohamad Nizam Jaafar
}

To Link this Article: http://dx.doi.org/10.6007/IJARBSS/v8-i11/4953

DOI: $10.6007 /$ IJARBSS/v8-i11/4953

Received: 23 Oct 2018, Revised: 11 Nov 2018, Accepted: 29 Nov 2018

Published Online: 06 Nov 2018

In-Text Citation: (Muhamat, Karim, Mainal, Alwi, \& Jaafar, 2018)

To Cite this Article: Muhamat, A. A., Karim, N. A., Mainal, S. A., Alwi, S. F. S., \& Jaafar, M. N. (2018). Determinants of Agents Performance: A Case Study of AmMetLife Malaysia Berhad. International Journal of Academic Research in Business and Social Sciences, 8(11), 768-778.

Copyright: (C) 2018 The Author(s)

Published by Human Resource Management Academic Research Society (www.hrmars.com)

This article is published under the Creative Commons Attribution (CC BY 4.0) license. Anyone may reproduce, distribute, translate and create derivative works of this article (for both commercial and non-commercial purposes), subject to full attribution to the original publication and authors. The full terms of this license may be seen

at: http://creativecommons.org/licences/by/4.0/legalcode

Vol. 8, No. 11, 2018, Pg. 768 - 778

http://hrmars.com/index.php/pages/detail/IJARBSS

JOURNAL HOMEPAGE

Full Terms \& Conditions of access and use can be found at http://hrmars.com/index.php/pages/detail/publication-ethics 


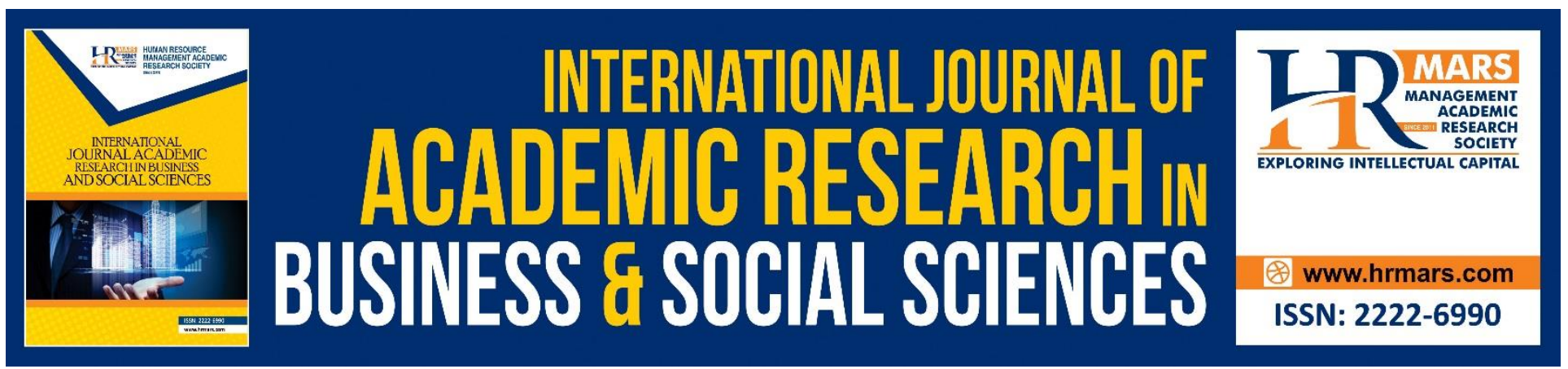

\title{
Determinants of Agents Performance: A Case Study of AmMetLife Malaysia Berhad
}

\author{
Amirul Afif Muhamat ${ }^{1}$, Norzitah Abdul Karim², Siti Aminah Mainal ${ }^{3}$, \\ Sharifah Faigah Syed Alwi ${ }^{4}$ \& Mohamad Nizam Jaafar ${ }^{5}$ \\ 1,2,3 Faculty of Business \& Management, Universiti Teknologi MARA (Selangor), Puncak Alam \\ Campus, 42300 Selangor, Malaysia \\ ${ }^{4,5}$ Arshad Ayub Graduate Business School, Universiti Teknologi MARA, Shah Alam Campus, a40450 \\ Malaysia
}

\begin{abstract}
Agents are the sales force of insurance companies or takaful operators. Nevertheless, agents are not the insurer's staff; rather they are external party who are interested to be affiliated with the insurer by being compensated in form of commission when they managed to close new case (able to get new policyholder). This study appraised factors that influence AmMetLife Berhad's agency performance which are: agent's retention; customer recruitment; insurer's brand; and sales activity. This study employed questionnaires which were distributed to 60 agents of AmMetLife who are attached to central, northern and southern region. Limitation of this study is that the agents from East Coast and East Malaysia are not surveyed due to the distance and they normally have separated training sessions compared with the central, northern and southern regions which normally have joint-session. Nevertheless, the three regions in the peninsular Malaysia have represented nearly $80 \%-90 \%$ from the total AmMetLife agents in the country. Most of the agencies' members agreed that they would rely on company/agency incentive to drive the sales. Moreover, customer recruitment and insurer's brand indicate positive but weak relationship towards the agency performance. In contrast, the other two factors which are agent retention and sales activity display positive and significant relationship for the agency performance.
\end{abstract}

Keywords: Agent Retention, Recruitment, Incentive, Insurance, Takaful

\section{Introduction}

There are 16 insurance companies in Malaysia as at October 2017 according to Life Insurance Association of Malaysia (LIAM) website. The top three that has always been called as the 'big boys' of the industries are AIA, Great Eastern and Prudential due to their long period of operation in the country. It will take a long period of time for other companies to compete and surpass these top three insurance companies. Although these top three companies have a range of 15,000-19,000 life 
insurance agents nationwide - a significant number of insurance agents, they also experienced the same struggle in expanding their businesses.

This study assesses the challenges that AmMetLife Insurance Bhd faces with regards to agents performance. AmMetLife is a joint venture company between AmLife and MetLife in the year 2014. MetLife is Hong Kong based company and has been known worldwide and has become one of the top insurance companies Asia. They entered the Malaysian insurance industry through merger with one of the AmBank subsidiaries which is AmLife, or which previously known as AmAssurance. Hence since year 2014, the name has change to AmMetLife Insurance Bhd and AmMetLife Takaful Berhad. Since 2014, AmMetLife Insurance Berhad has gone through a lot of changes particularly on the structure of the organization so that the company is able to move forward by capitalizing on the advantage gained through the merger. During that year, the company has only 1,000 active agents from 200 agencies. The number is much smaller than other insurance companies.

In 2015, a lot of sales driven incentives were given to attract agents' attention by emphasising on the prospects of becoming insurance agent as career with AmMetLife.

There were various incentives which have been issued in the past; for short and long-term incentivies. It seems workable for some time and performance was noticeable in term of increment of policies closed. However, after some time, the problem happens again. AmMetLife Berhad has three distribution channels: agency; banca; and as part of employees' benefits (medical benefit for AmBank Group employees). Like other insurance and takaful companies, agency is the main contributor for company's sales and holds the largest portfolio among other distribution channels. Nevertheless, for 2017, banca and employee benefits has exceeded their sales target which caused agency to be the lowest contributor for AmMetLife Berhad.

Therefore, this study appraised on the factors that influence the AmMetLife Berhad agents' performance.

\section{Literature Review}

Agency is a group of agents that carry out the insurance selling practice with a guide from their manager and support from the insurer. An agent is a person who has the authority to act on behalf of another person between the insurer. The task of the agent is to bring (as well as represent) a contract between the insurer and a third person who is referred to as a "financial consumer".

An insurance agent is defined by the Financial Services Act 2013 as a person who does all or any of the followings:

a) Solicits or obtains a proposal for insurance on behalf or an insurer

b) Offers or assumes to act on behalf of an insurer in negotiating a policy

c) Represents the insurer re issuance, renewal or continuance of a policy

An insurance agent is expected to inform the potential customer about the salient features of the product and to guide the potential customer by providing full disclosure of materials and facts so that the customer can proceed with an informed decision. Therefore, it signifies the critical role that an insurance or takaful agent has to play. Moreover, majority of the policyholders in Malaysia are not familiar with insurance and financial terms and they also do not bother to read the policy book and often do not even remember the coverage or entitlements that they had bought. 
Other than that, when it comes to insurance or takaful claims; agents assistance is required to ease the daunting process. Even though the process is transparent in the sense that there is a flow that needs to be followed; but it is bureaucratic process to ensure that fraud does not happen and the policyholder receives the benefits that are entitled to. It is a common sight for the beneficiary to be in a state of clueless upon the death of policyholder because they are mixed with emotions. This is the time for agent to carry out the duty by comforting the deceased family members and assure them that the family is still in a good hand.

\section{Agent Retention}

Life Insurance Marketing and Research Association (LIMRA) notes that commission is the core motive that encourages the insurance sales representatives or agents to work hard to close new insurance case. Nevertheless, that does not infer there is no issue that affect the agents. Stevens (2008) and LIMRA (as cited in Omboi, 2011) agree that the turnover rate in the industry is one of the highest and alarming.

LIMRA points out that, it has been of great concern to many managers, the fact that many sales representatives who join the industry and become successful out of $100 \%$ who are recruited in the sales force only $5 \%$ remain in the industry and become successful sales representatives, out of $5 \%$ only $2 \%$ become high achievers in the industry. Burand (as cited in Omboi, 2011) notes that over time, agents' retention in the life insurance industry remains a perennial challenge for companies operating within the traditional career agency system. According to LIMRA (as cited in Omboi, 2011), 68\% of agents leave companies within their first two years.

In 2005, the four-year agent retention rate was $14 \%$ with a total annual turnover rate of $31 \%$ (Annual Agent Production and Survival Survey, as cited in Omboi, 2011). Although this retention percentage did increase in 2005, over the past 20 years, agent retention has been unable to dramatically increase. Companies are losing money because it takes an enormous amount of resources to recruit, hire and train new agents. LIMRA estimates that it costs anywhere from $\$ 65,000$ to $\$ 215,000$ to develop a new agent through the first three years of his or her career. Expenses to recruit and maintain is high hence it is huge money for a company to see the result from the expenses given out (as cited in Omboi, 2011).

Cravens (as cited in Omboi, 2011) points out that, life insurance industry can be difficult business to get started in, but with the right tools and training a person can become successful at selling life insurance products. Selling life insurance product is not easy, that is why even though the commission earning is much more than being employed, not many people can sustain in this career which leads to a high turnover or low retention rate. AmMetLife is not excluded as from 120 new recruits in 2016, only $20 \%$ are still in the career after the 6 month.

Frankas (2010) eludes that, for insurance sales agents' job, most companies and independent agencies prefer to hire college graduates-especially those who have majored in business or economics whereas high school graduates are occasionally hired if they have proven sales ability or have been successful in other type of work (as cited in Omboi, 2011).

\section{- Recruitment}

As pointed out by Mainelli and Giffords (as cited in Ng, Chong, \& Ismail, 2012) firms larger in size can enjoy economies of scale and scope, and also pass an important criterion to enable them to sompete 
INTERNATIONAL JOURNAL OF ACADEMIC RESEARCH IN BUSINESS AND SOCIAL SCIENCES Vol. 8, No. 11, Nov, 2018, E-ISSN: 2222-6990 @ 2018 HRMARS

globally. According to Boyd and Runkle (1993), with reference to the theory of modern intermediation, a larger firm is more cost efficient and less likely to fail. This theory suggests that being bigger proffers an advantage in reducing pooled risks through a large number of contracting parties, thereby reducing the possibility of failure. As such, larger institutions are believed to have more profitable investment opportunities, higher efficient, more diversification and a lower risk level. Consistently, Boyd and Runkle (1993) findings suggest an inverse relationship between firm size and assets return volatility.

In view of the above findings, it can be said that, for life insurance Company to be bigger and more efficient, they need to have more agents. This is because, according to LIAM, insurance services delivery is undertaking by company direct marketing through brokers and by insurance agents. In the case of AmMetLife, agents are the most important delivery system. The bigger the agency force, the bigger the performance will be. Logically, with the same number of agents, company unable to expect growth of $200 \%$ compare to previous year without more manpower. Hence recruitment is very crucial.

AmMetLife recruitment strategies are by conducting AmMetLife Career Talk (El-Gamal) on monthly basis. Agents and leaders will need to send invitation to their respective potential candidate to attend to the ACT. Company would arrange a speaker that will emphasize on the opportunity, reward and benefits when a person join career as insurance agent. Statistically in AmMetLife, averagely in 10 invitees, 7 will turn up, 3 will sign up for exam, 1 will be contracted. This number relatively low as compared to the industry ACT held by other company.

\section{- Branding}

There are 16 life insurance companies in Malaysia. When it comes to customer buying decision, the life insurance company brand standing is one of the criteria they are looking at besides the relationship with the agents and the needs. Even though all life insurance companies in Malaysia are ruled under Bank Negara and LIAM - the company's image (AÏT-SAHALIA \& BRANDT) still play important role.

The top 3 insurers in Malaysia are known as AIA, Great Eastern and Prudential. These companies have been in the industry for a very long period of time which makes them the leaders of the industry which carry a strong brand name. With a good branding, will make it easier for agents to make sales and build confidence in the potential customers.

It takes time to establish a good branding in the market especially in term of financial. That is why insurance company as one of the financial institution need to establish their name in a good way but not taking very long time.

AmMetLife Insurance Berhad ("AmMetLife") (formerly known as AmLife Insurance Berhad) is a longestablished insurer (incorporated on 17 September 1973) in Malaysia. AmMetLife is a strategic partnership between AMMB Holdings Berhad ("AmBank Group") and MetLife International Holdings,Inc. They have merged on April 30, 2014 and leveraging on the shared core values of integrity and innovation, AmMetLife aims to be a leading customer centric and modern insurer in Malaysia. (AmMetLife Insurance Berhad)

AmMetLife need to develop their company name and promote it extensively so that people would notice the existence of the company. There is still huge opportunity for marketing to promote the 
company to reach to as many people as possible and currently only those who involve and have friends or family working with the company would know AmMetLife.

Life insurance industries are going through growing consumerism, changing consumer choices and expectations due to increase in education levels and growing personal wealth (Zamani, 2007). Furthermore, with the large unexploited market that still exists with $42.9 \%$ of the population or about 16 million people not having any of life insurance or family 'takaful' policy (Dhesi, as cited in Kumar Piaralal, Mat, Kumar Piaralal, \& Awais Bhatti, 2014). The complaints on life insurance also continue to increase from 485 in 2004 to 696 in 2005 (Insurance Annual Report,2005) and it is a proof for the dissatisfaction of customer towards local insurance industry.

With those indications, it is vital that insurance companies in Malaysia to search for trusted, qualified, knowledgeable, superior skills and experienced staffs and to retain hardworking employees to tap the market and serve the customers better. This is according to a study of relationship marketing in the life insurance industry which found that client satisfaction with the service is depended on their contact person or agent (Crosby \& Stephens, 1987).

Training of staff in job-related ability and behavioral skills to develop their capability is essential to overcome different customer requirement, personalities and circumstances in offering perfect service quality (Yavas et al., as cited in Piaralal, Bhatti, Piaralal, \& Juhari, 2016). All these training and finding the right people for the right job is essential in building the brand name in the industry. As agents and front-line staffs are the first line contact person who deals with customers, choosing the right persons are very crucial as they will bring the company name. A bad experienced by a customer, will lead bad review to the company instead of the individual staff or agents name.

\section{- Sales activity}

Teamwork has positive effects on organizational performance, as it can help to identify problems of the organization more accurately and find proper solutions to problems, effective ways of to include employees in the management, share information and communication in the organization, and it also generates energy and synergy in the organization and increases innovation and creativity (Ardahan, as cited in Kumar Piaralal et al., 2014).

There is a strong relationship between team work and increase in productivity and learning based on a sample of 575 team members and 145 project managers from German groups (Hoegi and Gemunenden, as cited in Al-Jedaiah, Tawfiqabdelhadi, \& Al-Maani, 2012).

Based on statement above, it can be concluded that a good team work will make a good sales activity. As according to Kumar Piaralal et al. (2014) most life insurance companies in Malaysia emphasize on four main areas, namely, knowledge, attitude, skills and habits in their training programmed. These 4 main criteria is important in developing a good sales habits.

Each insurance company or even agencies will have their own culture in driving sales activity. Culture is defined by Hofstede (1991) as a "collective phenomenon", as it is a shared with people who live or lived within the same social environment. Culture can affect the way people act, think and behave. According to AmMetLife statistic, 10 approaches will lead to 5 appointments which will lead to 3 closing interviews with a result of 1 sale. Following this, to get 1 sale, an agent needs to approach 10 potential customers. These are the activity that the agents need to do every day. Most of agents are afraid to approach as they scared of the rejection from the customer. According to Manmohan Singh (MDRT President and Agency Leader in AIA), he will ask his agents to go out and come back with 50 
rejections. Along his experienced none of the agents will succeed on bringing back 50 rejections in a day as they sure will be people that will say yes and buy. This tactic was just to create an activity for the agents to go out and approach people.

\section{Methodology}

This study employed questionnaires which were distributed to 60 agents of AmMetLife who are attached to central, northern and southern region. Limitation of this study is that the agents from East Coast and East Malaysia are not surveyed due to the distance and they normally have separated sessions compared with the central, northern and southern regions which normally will have jointsession. Nevertheless, the three regions in the peninsular Malaysia have represented nearly $80 \%$ 90\% from the total AmMetLife agents in the country. Questionnaire is developed based on 5-Likert scale options to be chosen reflecting the respondents' opinions. Personally administered questionnaire is used so that any clarification can be given during the session.

\section{Results}

Findings from the questionnaire survey are as follows:

\begin{tabular}{|c|c|}
\hline Cronbach's Alpha & Result \\
\hline .778 & Good \\
\hline
\end{tabular}

Table 1 Reliability Analysis: Cronbach's Alpha 
INTERNATIONAL JOURNAL OF ACADEMIC RESEARCH IN BUSINESS AND SOCIAL SCIENCES Vol. 8, No. 11, Nov, 2018, E-ISSN: 2222-6990 (C) 2018 HRMARS

Based on table 1, reliability for this study is in the range of acceptable to good as it is almost to 0.8 by point basis.

\begin{tabular}{|c|c|c|c|c|c|c|}
\hline & & Performance & Branding & Recruitment & $\begin{array}{c}\text { Agents' } \\
\text { Retention }\end{array}$ & $\begin{array}{c}\text { Sales } \\
\text { Activity }\end{array}$ \\
\hline \multirow[t]{3}{*}{ Performance } & $\begin{array}{l}\text { Pearson } \\
\text { Correlation }\end{array}$ & 1 & $.393^{* *}$ & $.347^{* *}$ & $.500^{* *}$ & $.602^{* *}$ \\
\hline & Sig. (2-tailed) & & .002 & .007 & .000 & .000 \\
\hline & $\mathrm{N}$ & 60 & 60 & 60 & 60 & 60 \\
\hline \multirow[t]{3}{*}{ Branding } & $\begin{array}{l}\text { Pearson } \\
\text { Correlation }\end{array}$ & $.393^{* *}$ & 1 & $.526^{* *}$ & $.522^{* *}$ & $.378^{* *}$ \\
\hline & Sig. (2-tailed) & .002 & & .000 & .000 & .003 \\
\hline & $\mathrm{N}$ & 60 & 60 & 60 & 60 & 60 \\
\hline \multirow[t]{3}{*}{ Recruitment } & \begin{tabular}{|l|} 
Pearson \\
Correlation
\end{tabular} & $.347^{* *}$ & $.526^{* *}$ & 1 & $.376^{* *}$ & $.341^{* *}$ \\
\hline & Sig. (2-tailed) & .007 & .000 & & .003 & .008 \\
\hline & $\mathrm{N}$ & 60 & 60 & 60 & 60 & 60 \\
\hline \multirow[t]{3}{*}{$\begin{array}{l}\text { Agents' } \\
\text { Retention }\end{array}$} & $\begin{array}{l}\text { Pearson } \\
\text { Correlation }\end{array}$ & $.500^{* *}$ & $.522^{* *}$ & $.376^{* *}$ & 1 & $.434^{* *}$ \\
\hline & Sig. (2-tailed) & .000 & .000 & .003 & & .001 \\
\hline & $\mathrm{N}$ & 60 & 60 & 60 & 60 & 60 \\
\hline \multirow[t]{3}{*}{ Sales Activity } & $\begin{array}{l}\text { Pearson } \\
\text { Correlation }\end{array}$ & $.602^{* *}$ & $.378^{* *}$ & $.341^{* *}$ & $.434^{* *}$ & 1 \\
\hline & Sig. (2-tailed) & .000 & .003 & .008 & .001 & \\
\hline & $\mathrm{N}$ & 60 & 60 & 60 & 60 & 60 \\
\hline
\end{tabular}

$* *$. Correlation is significant at the 0.01 level (2-tailed).

Table 2 Correlation Analysis

From table 2 above, it shows that all independent variables have a positive relationship towards the dependent variable. Independent variables of agents' retention and sales activity have a strong positive relationship while branding and recruitment shows weak positive relationship towards the dependent variable. Sales activity contributes to $\mathrm{R}=0.602$ or $60.2 \%$ where is it significant at 0.000 level $(p<0.01)$. Strong positive correlation shows that an increase in sales activity will lead to an increase in manpower. Agents' retention also shows a strong positive relationship which contributes $\mathrm{R}=0.500$ or $50 \%$ at a par level. This indicates an increase in agents' retention will give positive impact in manpower.

Branding and recruitment correlation is at $\mathrm{R}=0.393$ or $39.3 \%$ and $\mathrm{R}=0.347$ or $34.7 \%$ respectively. It can be determined that both independent variables show a weak positive relationship. In view to that correlation, the level of significance is $p<0.05$. According to Pallant (2010), this is to prove that 95 or 99 times out of $100 \%$ of a relationship can be said that is having a true or significant correlation. Meanwhile, it can be ascertained that there is only $5 \%$ or $1 \%$ chance that the relationship does not exist. 
INTERNATIONAL JOURNAL OF ACADEMIC RESEARCH IN BUSINESS AND SOCIAL SCIENCES

Vol. 8, No. 11, Nov, 2018, E-ISSN: 2222-6990 C 2018 HRMARS

\section{Multicollinearity test}

\begin{tabular}{|l|c|c|}
\hline \multirow{2}{*}{ Model } & \multicolumn{2}{|c|}{ Collinearity Statistics } \\
\cline { 2 - 3 } & Tolerance & VIF \\
\hline Branding & .592 & 1.689 \\
\hline Recruitment & .694 & 1.440 \\
\hline Agents' Retention & .656 & 1.523 \\
\hline Sales Activity & .763 & 1.311 \\
\hline
\end{tabular}

Table 3 Collinearity Statistics

Table 3 is the outcome for tolerance and variation inflation factors (VIF) test. According to the table, all the independent variables have tolerance values greater than 0.10 and the VIF values are less than 5.0. Therefore, this study does not suffer from multicollinearity issue because it only exists if the tolerance value is lower than 0.1 and VIF value is greater than 5.0.

\section{Regression Analysis}

Model Summary
\begin{tabular}{|l|c|c|c|c|}
\hline Model & $\mathrm{R}$ & $\mathrm{r}^{2}$ & Adjusted R Square & Std. Error of the Estimate \\
\hline 1 & $.664^{\mathrm{a}}$ & .441 & .401 & .635 \\
\hline
\end{tabular}

Table 4: Coefficient Analysis, $r^{2}$

Table 4 indicates that the value of $R$ shows the dependent variable can be explained by the changes in the independent variables. The linear regression test of the model reveals that $r^{2}=0.441$, which means that $44.1 \%$ of the variance in the dependent variable can be explained by the whole variable. Meanwhile, the remaining $59.9 \%$ is explained by the other factors.

\section{Multiple Regression Analysis}

\begin{tabular}{|l|c|c|c|c|c|}
\hline \multirow{2}{*}{ Model } & \multicolumn{2}{|c|}{$\begin{array}{c}\text { Unstandardized } \\
\text { Coefficients }\end{array}$} & $\begin{array}{c}\text { Standardized } \\
\text { Coefficients }\end{array}$ & & \\
\cline { 2 - 4 } & $\mathrm{B}$ & Std. Error & Beta & $\mathrm{t}$ & Sig. \\
\hline Branding &. .150 & .746 & & -.201 & .841 \\
\hline Recruitment & .084 & .194 & .057 & .432 & .667 \\
\hline $\begin{array}{l}\text { Agents' } \\
\text { Retention }\end{array}$ & .099 & .169 & .071 & .586 & .560 \\
\hline Sales Activity & .586 & .186 & .249 & 2.002 & .050 \\
\hline
\end{tabular}

Table 5: Multiple Regression Analysis

From table 5 above, shows the significant relationship of the independent variables and the coefficient. Branding has no significant value, which is 0.667 . The coefficient is 0.084 shows that branding is positively correlated with manpower. It explains that there is a positive relationship between both variables. The coefficient value indicates that any $1 \%$ increase in branding will cause an increase in manpower of the respondents by 0.084 . Recruitment also has no significant value 
which is 0.560 . The coefficient is 0.099 shows that recruitment is positively correlated with manpower to increase agency performance. The coefficient value indicates that any $1 \%$ increase in recruitment will cause an increase in manpower of the respondent by 0.099. Agents' retention has a significant value of 0.050 . The coefficient is 0.372 shows that the variable is positively correlated with manpower to increase agency performance. It explains that there is a positively relationship between agents' retention and manpower. The coefficient value indicates that any $1 \%$ increase in agents' retention will cause and increase of respondents by 0.372 . The last independent variable is sales activity. Sales activity has a significant value of 0.000 . The coefficient is 0.586 shows that the variable is positively correlated with manpower to increase agency performance. It explains that there is a positive relationship between sales activity and manpower. The coefficient value indicates that any $1 \%$ increase in sales activity will cause and increase in the intention of the respondent by 0.586 .

\section{Conclusion}

The study concludes that agent's retention and sales activity are the significant and critical factors that determine insurance as well as takaful operators' agency performance. Brand and recruitment are not considered significant in this study but still needs to be given proper attention because they are part and parcel of the business components in this industry.

Limitation of the study is that the East-Coast and East Malaysia agents are not covered. For future study, it would be recommended to study on the agents' performance from all takaful operators and insurance companies in Malaysia so that it will represent comprehensive industry's experiences.

\section{Acknowledgement}

We would like to thank you Mastura Mohd Nor for her invaluable contribution towards this study.

\section{Corresponding Author}

Amirul Afif Muhamat, Faculty of Business \& Management, Universiti Teknologi MARA, Malaysia, Email: amirulafif@salam.uitm.edu.my

\section{References}

Ait-Sahalia, Y., \& Brandt, M. W. (2001). Variable Selection for Portfolio Choice. The Journal of Finance, Vol. LVI, No. 4, 1297-1348.

Al-Jedaiah, M. N., Tawfiqabdelhadi, \& Al-Maani, A. (2012). The relationship between forming team work, knowledge, learning and creativity improvement in high technology companies in Jordan. An empirical study (HSBC bank).

AmMetLife Insurance Berhad. About Us. Retrieved from https://www.ammetlife.com/life/about-us

Boyd, J. H., \& Runkle, D. E. (1993). Size and performance of banking firms: Testing the predictions of theory. Journal of monetary economics, 31(1), 47-67. 
INTERNATIONAL JOURNAL OF ACADEMIC RESEARCH IN BUSINESS AND SOCIAL SCIENCES

Vol. 8, No. 11, Nov, 2018, E-ISSN: 2222-6990 (C) 2018 HRMARS

Crosby, L. A., \& Stephens, N. (1987). Effects of relationship marketing on satisfaction, retention, and prices in the life insurance industry. Journal of marketing research, 404-411.

El-Gamal, M. A. I. F. L., Economics and Practice. (2006). Islamic Finance: Law, Economics and Practice. New York: Cambridge University Press.

Hofstede, G. (1991). Cultures and Organizations: Software of the Mind.: McGraw-Hill.

Kumar Piaralal, N., Mat, N., Kumar Piaralal, S., \& Awais Bhatti, M. (2014). Human resource management factors and service recovery performance in Malaysian life insurance industry. European Journal of Training and Development, 38(6), 524-552. doi:10.1108/ejtd-07-20130078

Mews, C., \& Abraham, I. (2007). Usury and just compensation: religious and financial ethics in historical perspective. Journal of Business Ethics, 72(1), 1-15. doi:10.1007/s10551-006-91510

Ng, T. H., Chong, L. L., \& Ismail, H. (2012). Is the risk management committee only a procedural compliance? The Journal of Risk Finance, 14(1), 71-86. doi:10.1108/15265941311288112

Omboi, B. M. (2011). Factors Influencing Agents Retention In Insurance Industry: A Survey Of Selected Insurance Companies In Nairobi (Kenya).

Piaralal, S. K., Bhatti, M. A., Piaralal, N. K., \& Juhari, A. S. (2016). Factors affecting service recovery performance and customer service employees. International Journal of Productivity and Performance Management, 65(7), 898-924. doi:10.1108/ijppm-04-2014-0060 